\title{
SIGNIFICANCE OF THE RED FOX AS A NATURAL RESERVOIR OF INTESTINAL ZOONOSES IN VOJVODINA, SERBIA
}

\author{
Milan MILJEVIĆ ${ }^{1 *}$, Olivera BJELIĆ ČABRILO ${ }^{2}$, Verica SIMIN ${ }^{3}$, Borislav ČABRILO ${ }^{2}$, \\ Jelena BoganČ MILJEviĆ ${ }^{4}$ and Dušan LALOŠEVIĆ ${ }^{3}$ \\ ${ }^{1}$ Department of Genetic Research, Institute for Biological Research 'Siniša Stanković', \\ University of Belgrade, Bulevar Despota Stefana 142, 11060, Belgrade, Serbia; \\ ${ }^{2}$ University of Novi Sad, Faculty of Sciences, Novi Sad, Serbia; ${ }^{3}$ Pasteur Institute of \\ Novi Sad, Novi Sad, Serbia; ${ }^{4}$ Clinic for Nephrology and Clinical Immunology, \\ Clinical Center of Vojvodina, Novi Sad, Serbia
}

(Received 19 July 2019; accepted 17 September 2019)

In the present study, 223 foxes were collected from various localities in the northern part of the Republic of Serbia (Vojvodina province) and examined for intestinal helminths. Among the examined foxes 178 (79.8\%) were infected. The most frequently identified parasites were Mesocestoides spp. (49.3\%) and Toxascaris leonina $(36.3 \%)$. The parasite with the lowest prevalence was Pterygodermatites affinis $(0.9 \%)$, and this is the first confirmed finding in Serbia. The other recovered species were Alaria alata (25.6\%), Taenia spp. (6.3\%), Echinococcus multilocularis (13\%), Toxocara canis (16.6\%) and Uncinaria stenocephala $(14.8 \%)$. The highest number of foxes infected with E. multilocularis were in the Srem area. The results of this study indicate the presence of helminth species in red foxes in Vojvodina which may also infect humans. dina

Key words: Red fox, helminth, Carnivora, echinococcosis, Serbia, Vojvo-

The red fox (Vulpes vulpes L., 1758) belongs to the order Carnivora and is widely distributed worldwide. An increase in fox populations was noted in many European countries (Vervaeke et al., 2003; Goszczyński et al., 2008), explained by the effects of a successful rabies vaccination campaign of wild animals, an increase in anthropogenic food sources, and the impact of environmental factors (Gloor et al., 2001). At the same time, fox habitats extended into urban areas (Schweiger et al., 2007). A growing number of studies point to the colonisation of cities across Europe, the USA and Australia (Christensen, 1985; Adkins and Stott, 1998; Romig, 1999; Robinson and Marks, 2001). Following the trend seen in other European countries, red fox populations have been on the rise in Serbia as well.

\footnotetext{
*Corresponding author; E-mail: milan.miljevic@ibiss.bg.ac.rs; Phone: 00381 (11) 207-8332
} 
Due to the increased contact between humans and domestic animals on the one hand, and the appearance of populations of so-called urban foxes on the other, the risk of zoonotic transmission of parasitic diseases in urban areas is rising. A study conducted in Switzerland found an increase in the incidence of human alveolar echinococcosis since 2000 . This can be explained by the urbanisation of the Echinococcus multilocularis Leuckart, 1863 life cycle, due to an increase in the number of infected foxes in urban areas (Deplazes et al., 2004; Schweiger et al., 2007).

Foxes are permanent hosts of many types of helminths, some of which have significant zoonotic potential. One such parasite is the tapeworm E. multilocularis, a causative agent of alveolar echinococcosis. This parasite has been recorded in jackals and foxes in Serbia, on the territory of Vojvodina (Lalošević et al., 2016). The rich community and the wealth of parasite species found in foxes is associated with the ability of the host to exploit a wide range of habitats, which affects the availability of prey and the composition of the diet (Eira et al., 2006). The intestinal helminth fauna of red foxes has been well researched throughout Europe (Vervaeke et al., 2005; Eira et al., 2006; Magi et al., 2009; Miterpakova et al., 2009; Vergles-Rataj et al., 2013).

The importance of foxes as natural reservoirs and distributors of zoonotic infections, as well as the deficiency of data on population infections in Vojvodina have indicated the need for more detailed and systematic research. Studies on the helminth fauna conducted in Serbia do not provide a complete epidemiological presentation of the helminth fauna of Vojvodina. The aim of this study was to investigate the prevalence of intestinal helminths of red foxes in all seven districts of this area.

\section{Materials and methods}

The Province of Vojvodina occupies the northern part of the Republic of Serbia. It spreads through the Pannonian Plain with an area of $21,506 \mathrm{~km}^{2}$, which represents $24.9 \%$ of the total territory of Serbia. It borders Hungary to the north, Romania to the east, the River Danube and Sava to the south, Croatia to the west, and Bosnia and Herzegovina to the far southwest. There are three regions within Vojvodina, Srem, Banat and Bačka, which are administratively divided into 7 districts (Fig. 1). Bačka and Banat are mainly flat with arable land, while the landscape of Srem is dominated by the Fruška Gora mountain.

From all 7 districts of Vojvodina, 223 red foxes were collected between January 2015 and February 2018, as part of the routine rabies diagnostic procedure in the Pasteur Institute of Novi Sad, National Reference Laboratory for Rabies. After autopsy, the intestines were washed and parasites collected and determined morphologically. The intestinal scraping technique (SCT) according to Eckert et al. (2001) was also used for the detection of parasite infection. 


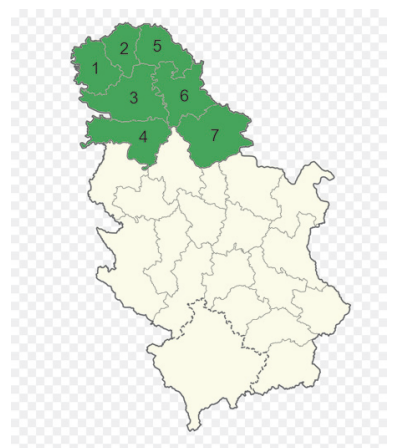

Fig. 1. Location of Vojvodina (green) within Serbia with each of the seven districts demarcated by a border. 1 - West Bačka, 2 - North Bačka, 3 - South Bačka, 4 - Srem, 5 - North Banat, 6 - Central Banat, 7 - South Banat

All quantitative parameters of intestinal helminth infection follow the guidelines of Bush et al. (1997), and were calculated in QPweb (Reiczigel et al., 2019), along with $95 \%$ confidence intervals. The dispersion index (d) was also calculated, as a measure of parasite aggregation within hosts (Shaw and Dobson, 1995). Dispersion index values higher than 1 indicate an aggregated distribution of parasites.

\section{Results}

Intestinal parasites were detected in 178 red foxes, resulting in a total prevalence of 79.8\%. Mesocestoides spp. Vaillant, 1863 (49.3\%) and Toxascaris leonina (Linstow, 1902) (36.3\%) were the most prevalent parasite species (Table 1). The parasite with the lowest prevalence was Pterygodermatites affinis (Jagerskiold, 1904), which was found in only two foxes $(0.9 \%)$ collected in 2017 . To the best of our knowledge, this is the first confirmed finding of $P$. affinis in Serbia. The genus Pterygodermatites Wedl, 1861 is characterised by an apical oral opening, three oesophageal teeth and 29-58 pairs of prevulvar spines (Anderson et al., 2009). The species was identified on the grounds of specific morphological characteristics of two females: body length, egg size and the presence of two rows of cuticular combs or spines throughout the length of the body, which become more sparse and shorter towards the posterior end. The female tail has a spinal terminal spike (Ammar, 2015; Scioscia et al., 2016) (Fig. 2).

With regard to parasite abundance, the most numerous species was $E$. multilocularis, with 1,485 individuals. The second largest group of helminths was Mesocestoides spp. $(1,282)$, followed by the nematode Toxascaris leonina (483) and the trematode Alaria alata (Goeze, 1782) (429). Echinococcus multilocularis had the highest values of parameters such as mean abundance (6.7) and mean infection intensity (51.2) (Table 1). It was found in only one fox in Banat (1/58) (1.7\%), five foxes in Bačka (5/47) (10.6\%) and 23 foxes (23/118) $(19 \%)$ in Srem. 

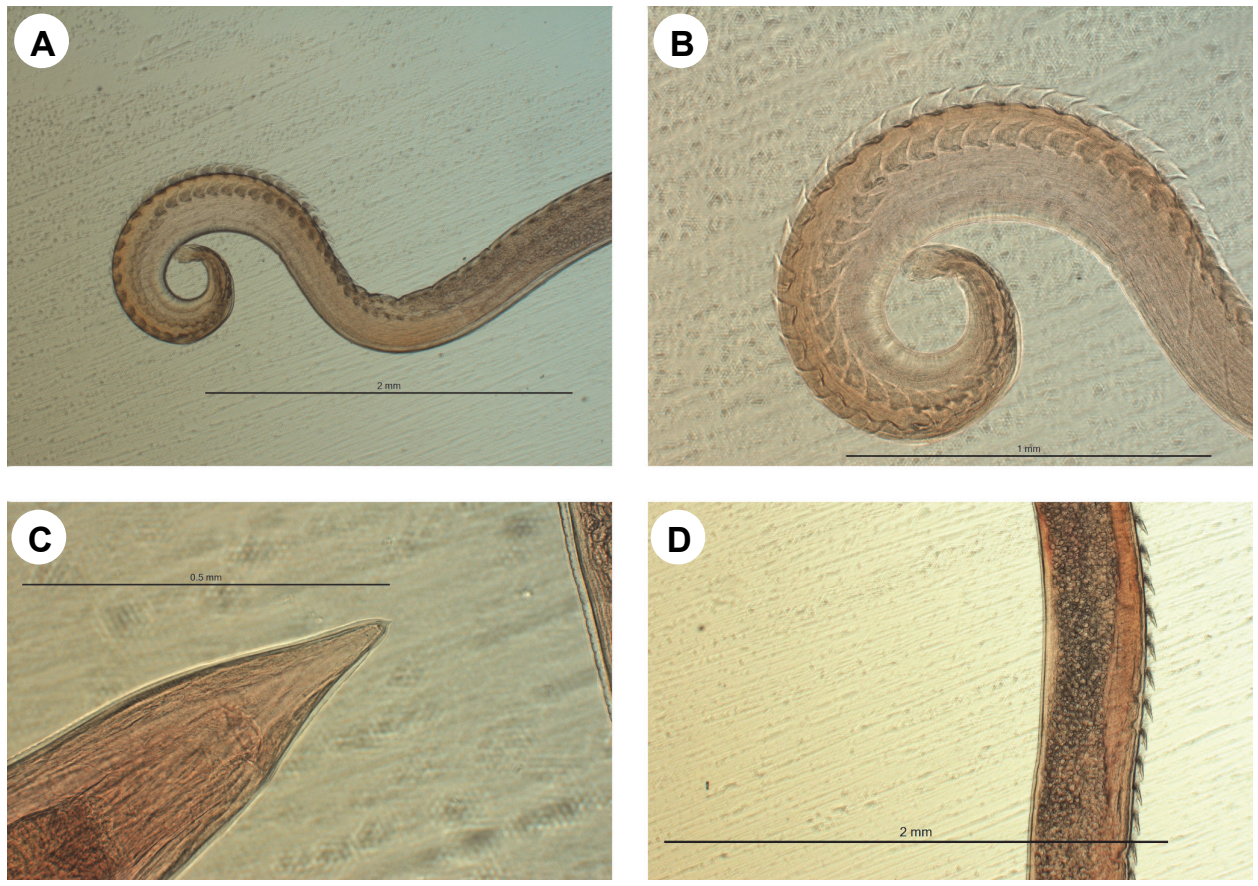

Fig. 2. Female Pterygodermatites affinis specimen found in a red fox in Vojvodina. A - anterior end of female, $\mathrm{B}$ - detail of anterior end with visible spines, $\mathrm{C}$ - posterior end of female with visible terminal spike, D - eggs

Table 1

Quantitative parameters of intestinal helminth infection of the examined red foxes in Vojvodina

\begin{tabular}{lccccc}
\hline Endoparasite species & $\mathrm{P}(\%)$ & $\mathrm{MA}$ & $\mathrm{MI}$ & $\mathrm{R}$ & $\mathrm{d}$ \\
\hline Alaria alata & $25.6(20.1-31.8)$ & $1.9(1.1-3.5)$ & $7.5(4.7-13.9)$ & $1-90$ & 1 \\
Echinococcus & & & & & \\
multilocularis & $13.0(9.1-18.1)$ & $6.7(3.1-16.5)$ & $51.2(27.3-120)$ & $1-540$ & 36.6 \\
Taenia spp. & $6.3(3.7-10.3)$ & $0.1(0.06-0.2)$ & $1.9(1.4-2.6)$ & $1-5$ & 26.7 \\
Mesocestoides spp. & $49.3(42.8-56.1)$ & $5.8(4.4-7.9)$ & $11.7(9.3-15.6)$ & $1-100$ & 2.4 \\
Toxascaris leonina & $36.3(30.2-42.8)$ & $2.2(1.5-3)$ & $6(4.6-8.1)$ & $1-40$ & 249.8 \\
Toxocara canis & $16.6(12.1-22.2)$ & $0.3(0.2-0.4)$ & $1.7(1.4-2.4)$ & $1-6$ & 13.3 \\
\hline
\end{tabular}

$\mathrm{P}$ - prevalence, MA - mean abundance, $\mathrm{MI}$ - mean intensity, $\mathrm{R}$ - minimum-maximum range, $\mathrm{d}$ dispersion index; $95 \%$ confidence intervals in parentheses, where applicable

In the fox sample, one species of hookworm, identified as Uncinaria stenocephala (Railliet, 1884) was found, with a prevalence of $14.8 \%$. Additionally, the 
presence of parasitic tapeworms of the genus Taenia Linnaeus, 1758 was recorded in a relatively low percentage $(6.3 \%)$. In the present study, these tapeworms were not identified to the species level.

Multiple infections with intestinal helminths were frequently observed, and were more common $(61.4 \%)$ than infections with a single species. Intestinal infection with two species of parasites was found in $31.1 \%(55 / 177)$, three species in $22 \%(39 / 177)$, four species in $6.8 \%(12 / 177)$, and five species in $1.7 \%$ (3/177) of red foxes.

\section{Discussion}

Eight species of intestinal helminths were found in the examined animals, with varying prevalence values. The most prevalent parasites were Mesocestoides spp. tapeworms. A wide distribution of Mesocestoides spp. with a similar prevalence was observed in other European countries such as the Czech Republic (Jankovska et al., 2016: 40\%), Slovakia (Hrčkova et al., 2011: 41.9\%), Italy (Magi et al., 2009: 45.5\%) and Hungary (Széll et al., 2015: 45.8\%). Pavlović et al. (2008) found two Mesocestoides species in Serbia: M. lineatus with a prevalence of $37.98 \%$ and $M$. litteratus with a prevalence of $10.95 \%$. The latter species was recorded in Vojvodina for the first time. There are only two species within the genus Mesocestoides (M. variabilis and M. lineatus) that are recognised as possible causative agents of human infection. Fuentes et al. (2003) summarised 18 cases of human infections caused by M. lineatus in Japan, Korea and China.

Considering the pathogenicity of Mesocestoides tapeworms (Széll et al., 2015), their presence in the host sample is not to be overlooked. However, morphological differences between species in the genus are subtle, and determination is difficult without the use of molecular methods (Padgett et al., 2005). Since such analyses were not performed in the current study, and since it is unclear whether the foxes were infected via game birds or rodents, these tapeworms were identified only at genus level. Similarly, Taenia tapeworms were not identified at species level. They were characterised by low prevalence $(6.3 \%)$, corresponding to the results of other studies carried out in Serbia which reported $4.65 \%$ of foxes infected with these parasites (Ilić et al., 2016).

In a study conducted by Lalošević et al. (2016), E. multilocularis was recorded in red foxes in Vojvodina. The current study expands on these results by including other intestinal parasites from a larger host sample. Two years after the published finding of multilocular echinococcosis in Vojvodina, Beck et al. (2018) published the first report of E. multilocularis in the red fox in the neighbouring country of Croatia. By observing the distribution map of infected foxes in Croatia and Vojvodina, we can conclude that the distance between the two closest points is about $100 \mathrm{~km}$, and this raises questions about the possible connections between these areas. That the potential for red fox dispersal is not a limiting fac- 
tor is demonstrated by the fact that foxes can cover straight-line distances in excess of $108 \mathrm{~km}$ in 7 days (Walton et al., 2018). Based on these data, and taking into account the fact that the Danube acts as a barrier for foxes, we may explain why parts of Vojvodina north of the river (Bačka and Banat) have low prevalences of multilocular echinococcosis (only six infected foxes), while the hotspot of echinococcosis is in Srem, a region south of the Danube shared by Serbia and Croatia. Alveolar echinococcosis is one of the most dangerous zoonoses in the world. While there are cases of human infection in some European countries (Horváth et al., 2008; Szilágyiová et al., 2015), there are no documented cases of human alveolar echinococcosis in Serbia at the moment.

In a recent study, $A$. alata was found in the red fox with a prevalence of $25.6 \%$. In a previous study conducted in Serbia (Ilić et al., 2016), the prevalence was higher $(49.4 \%$ in foxes and $30 \%$ in jackals). In their review Möhl et al. (2009) summarise a large number of literature data on this species and state that about $30 \%$ of wild canids in Europe are carriers of $A$. alata, with a prevalence range from $0.1 \%$ in Germany to $88 \%$ in Poland. The authors also state that a particularly high rate of infection can be registered in omnivorous species, such as wild boars living in areas with a high prevalence of $A$. alata in definitive hosts. The first published finding of Alaria mesocercariae in wild boar meat in Serbia, in the province of Vojvodina, emphasised the importance of investigating the presence of this trematode in the red fox as the main reservoir of alariosis (Lalošević et al., 2014). The latest research in Serbia on the presence of mesocercariae in pigs (Gavrilović et al., 2019) confirms new cases of A. alata in wild boars, but also reports the first registered case of this parasite in domestic pigs in Serbia, again in Vojvodina. According to the authors, this is the only reported case of $A$. alata mesocercariae in domestic pigs over the past several decades in Europe. The life cycle of $A$. alata includes intermediate hosts such as snails of the genus Planorbis and amphibians, and is predominantly related to aquatic habitats in which suitable types of hosts are present. It is important to note that Vojvodina has a large quantity of water in the form of ponds, marshes, canals and large plain rivers with slow water flow (Tasić et al., 2007). Although there are no recorded human cases of alariosis, $A$. alata is a parasite that may affect human health.

Toxocarosis is one of the most widespread and economically most important zoonoses, but is nevertheless neglected in international public health in comparison with other helminthic diseases (Macpherson, 2013). Toxocara canis (Werner, 1782) was found in $16.1 \%$ of foxes in the present survey. Authors from other European countries reported higher prevalence for this species in fox populations: $37.1 \%$ and $38.3 \%$ in Portugal and Slovenia, respectively (Eira et al., 2006; Vergles-Rataj et al., 2013). Still higher values were recorded in the United Kingdom (55.9\%, Richards et al., 1995), Denmark (59.4\%, Saeed et al., 2006) and the Netherlands (73.7\%, Borgsteede, 1984). Outside Europe, the species has 
been found in Tunisia (Lahmar et al., 2014) and Kyrgyzstan (Ziadinov et al., 2010). According to Dybing et al. (2013), T. canis is also present in Australia. In Serbia, the prevalence of this nematode in red foxes was $49.4 \%$ (Ilić et al., 2016). High prevalence of $T$. canis in urban foxes could provide a source of infection for man and his pets (Richards et al., 1993). The main path of infection of humans is by ingestion of embryonated eggs from the soil, especially in urban areas and playgrounds, which is the reason why children are most exposed to infection (Lalošević et al., 1993).

Pterygodermatites affinis (syn. Rictularia affinis) is a rare parasitic nematode in Europe, registered in only a few countries. This species was found in two foxes $(0.9 \%)$ in our survey and, to the best of our knowledge, this constitutes the first confirmed finding of $P$. affinis in Serbia. Similarly low prevalences in foxes were reported in Slovenia (4.2\%; Vergles Rataj et al., 2013), France (4\%; Deblock et al., 1988), and Italy (5.3\%; Fiocchi et al., 2016). Higher prevalence was noted in Spain (54\%) (Martinez-Carrasco et al., 2007). Pterygodermatites affinis is a typical nematode of carnivores with an indirect life cycle, and the infection of definitive hosts depends on the frequency of intermediate hosts such as reptiles in their diet (Papadopoulos et al., 1997; Martinez-Carrasco et al., 2007). This nematode, although not often registered in publications, has been recorded in different types of carnivores outside Europe and shows cosmopolitan distribution. It was reported from jackals and foxes in Tunisia (Lahmar et al., 2014), coyotes in Canada (Liccioli et al., 2012), cougars in Oregon, USA (Rausch et al., 1983), and domestic cats in Dubai, United Arab Emirates (Schuster et al., 2009). Scioscia et al. (2016) published the first report of this nematode in Argentina, and it was the first case of $P$. affinis infection in the pampas fox (Lycalopex gymnocercus), a new species added to the list of definitive hosts of the parasite.

In the present study, Toxascaris leonina had the second highest prevalence value of all intestinal helminth species. Compared to our findings, the prevalence of $T$. leonina in foxes was significantly lower in other countries, ranging from $0.6 \%$ in Denmark, $1.5 \%$ in United Kingdom and $2.5 \%$ in Slovenia to $4.7 \%$ in Australia and 5.4\% in Italy (Richards et al., 1995; Saeed et al., 2006; Magi et al., 2009; Vergles-Rataj et al., 2013; Dybing et al., 2013). Higher percentage of infected foxes was found in Belgium (47.9\%; Vervaeke et al., 2005) and Turkey (65\%; Gicik et al., 2009). In a survey of the helminth fauna of foxes in Serbia, Lozanić (1966) cites a prevalence of $20.5 \%$. The presence of this nematode in a high number of examined foxes can be explained by favourable climatic conditions for this species in Vojvodina, as well as its simpler life cycle compared to other ascaridids.

One of the most prevalent intestinal nematodes of red foxes in Europe is Uncinaria stenocephala (Reperant et al., 2007; Fiocchi et al., 2016). This species has a worldwide distribution in dogs and wild canids (Otranto and Deplazes, 2019). In a review article, Seguel and Gottdenker (2017) quote that higher preva- 
lence of $U$. stenocephala is found in canids which inhabit temperate or circumboreal areas. The same authors also consider the influence of host spatial density on nematode prevalence. With higher spatial density, the number of infective larvae in soil increases. Cutaneous larva migrans (CLM) is a zoonotic disease caused by nematodes of the hookworm family, such as Ancylostoma caninum and, rarely, $U$. stenocephala. Humans can also be infected, but the life cycle of this parasite cannot be completed in a human host. In Europe, CLM is usually registered in travellers who return from tropical and subtropical countries. However, autochthonous human cases have been noted in Serbia and other European countries (Tomović et al., 2008; Perić et al., 2017; Gutiérrez García-Rodrigo et al., 2017). Tomović et al. (2008) published the first report of such infections in Serbia, stating that abiotic factors such as unusually hot and sunny weather with heavy rain in the summer of 2005 and 2006 created favourable conditions for parasite development in the soil.

In conclusion, the present study has shown that red foxes living in the Vojvodina area are hosts of numerous parasite species, some of which have veterinary and human medical importance. The results indicate that among other helminths E. multilocularis is present in the area. While data on the presence of intestinal helminth species parasitising the red fox is relevant in its own right, this study can also be seen as a preliminary report pointing to the need of future research in the field. This would particularly have to deal with the identification of Mesocestoides and Taenia species occurring in foxes in Vojvodina, as well as studying the extent of E. multilocularis presence and the patterns of its potential expansion into the northern part of Serbia.

\section{References}

Adkins, C. A. and Stott, P. (1998): Home ranges, movements and habitat associations of red foxes (Vulpes vulpes) in suburban Toronto, Ontario, Canada. Can. J. Zool. 244, 335-346.

Ammar, K. N. A. (2015): Spirurid infection Rictularia affinis Jaegerskiold, 1909 (Spirurida: Rictularidae) from Egyptian fox Vulpus niloticus E. Geoffroy Saint Hilaire, 1803 (Mammalia: Canida). Danish J. Med. Biol. Sci. 2015, 15-28.

Anderson, R. C., Chabaud, A. G. and Willmott, S. (eds) (2009): Keys to the Nematode Parasites of Vertebrates: Archival Volume. CABI Publishing, Wallingford/New York. 463 pp.

Beck, R., Mihaljević, Ž., Brezak, R., Bosnić, S., Janković, I. L. and Deplazes, P. (2018): First detection of Echinococcus multilocularis in Croatia. Parasitol. Res. 117, 617-621.

Borgsteede, F. H. M. (1984): Helminth parasites of wild foxes (Vulpes vulpes L.) in the Netherlands. Z. Parasitenkunde 70, 281-285.

Bush, A. O., Lafferty, K. D., Lotz, J. M. and Shostak, A. W. (1997): Parasitology meets ecology on its own terms: Margolis et al. revisited. J. Parasitol. 83, 575-583.

Christensen, H. (1985): Urban fox population in Oslo. Rev Ecol. 40, 185-186.

Deblock, S., Pétavy, A. F. and Gilot, B. (1988): Helminthes intestinaux du renard commun (Vulpes vulpes L.) dans le Massif central (France). Can. J. Zool. 66, 1562-1569.

Deplazes, P., Hegglin, D., Gloor, S. and Romig, T. (2004): Wilderness in the city: the urbanization of Echinococcus multilocularis. Trends Parasitol. 20, 77-84. 
Dybing, A., Patricia, A. and Fleming, P. (2013): Environmental conditions predict helminth prevalence in red fox in Western Australia. Int. J. Parasitol. Parasites Wildl. 13, 165-172.

Eckert, J., Deplazes, P., Craig, P. S., Gemmell, M. A., Gottstein, B., Heath, D. and Lightowlers, M. (2001): Echinococcosis in animals: clinical aspects, diagnosis and treatment. In: Eckert, J., Gemmell, M. A., Meslin, F.-X. and Pawlowski, Z. S. (eds) WHO/OIE Manual on Echinococcosis in Humans and Animals: A Public Health Problem of Global Concern. World Organization for Animal Health, Paris. pp. 72-99.

Eira, C., Vingada, J., Torres, J. and Miquel, J. (2006): The helminth community of the red fox, Vulpes vulpes, in Dunas de Mira (Portugal) and its effect on host condition. Wildl. Biol. Pract. 1, 26-36.

Fiocchi, A., Gustinelli, A., Gelmini, L., Rugna, G., Renzi, M., Fontana, M. C. and Poglayen, G. (2016): Helminth parasites of the red fox Vulpes vulpes (L., 1758) and the wolf Canis lupus italicus Altobello, 1921 in Emilia-Romagna, Italy. Ital. J. Zool. 83, 503-513.

Fuentes, M. V., Galan-Puchades, M. T. and Malone, J. B. (2003): A new case report of human Mesocestoides infection in the United States. Am. J. Trop. Med. Hyg. 68, 566-567.

Gavrilović, P., Pavlović, I. and Todorović, I. (2019): Alaria alata mesocercariae in domestic pigs and wild boars in South Banat, northern Serbia. Comp. Immunol. Microb. 63, 142-144.

Gicik, Z., Kara, M., Sali, B., Kiric, K. and Arslan, M. (2009): Intestinal parasites of red foxes (Vulpes vulpes L.) and their zoonotic importance for humans in Kars Province. Kafkas Univ. Vet. Fak. Derg. 15, 135-140.

Gloor, S., Bontadina, F., Hegglin, D., Deplazes, P. and Breitenmoser, U. (2001): The rise of urban fox populations in Switzerland. Mamm. Biol. 66, 155-164.

Goszczyński, J., Misiorowska, M. and Juszko, S. (2008): Changes in the density and spatial distribution of red fox dens and cub numbers in central Poland following rabies vaccination. Acta Theriol. 53, 121-127.

Gutiérrez García Rodrigo, C., Tous Romero, F. and Zarco Olivo, C. (2017): Cutaneous larva migrans, welcome to a warmer Europe. J. Eur. Acad. Dermatol. Venereol. 31, e33-e35.

Horváth, A., Patonay, A., Bánhegyi, D., Szlávik, J., Balázs, G., Görög, D. and Werling, K. (2008): The first case of human alveolar echinococcosis in Hungary [in Hungarian, with English abstract]. Orv. Hetil. 149, 795-799.

Hrčkova, G., Miterpakova, M., O’Connor, A., Šnábel, V. and Olson, P. D. (2011): Molecular and morphological circumscription of Mesocestoides tapeworms from red foxes (Vulpes vulpes) in central Europe. Parasitology 138, 638-647.

Ilić, T., Becskei, Z., Petrović, T., Polaček, V., Ristić, B., Milić, S. and Dimitrijević, S. (2016): Endoparasitic fauna of red foxes (Vulpes vulpes) and golden jackals (Canis aureus) in Serbia. Acta Parasitol. 61, 389-396.

Jankovska, I., Brozova, A., Mateju, Z., Langrova, I., Lukesova, D. and Sloup, V. (2016): Parasites with possible zoonotic potential in the small intestines of red foxes (Vulpes vulpes) from Northwest Bohemia (CzR). Helminthologia 53, 290-293.

Lahmar, S., Boufana, B., Boubaker, S. and Landolsi, F. (2014): Intestinal helminths of golden jackals and red foxes from Tunisia. Vet. Parasitol. 204, 297-303.

Lalošević, D., Gebauer, E. and Malenković, M. (1993): The role of toxocariasis in the etiology of hypereosinophilic syndrome in children. Med. Pregl. 46, 434- 437.

Lalošević, D., Lalošević, V., Putić, S., Simin, S. and Kuruca, Lj. (2014): Alaria alata mesocercariae in the meat of a wild boar: a newly recorded pathogen in Serbia [in Serbian]. Med. Data 6, 363-365.

Lalošević, D., Lalošević, V., Simin, V., Miljević, M., Čabrilo, B. and Bjelić Čabrilo, O. (2016): Spreading of multilocular echinococcosis in southern Europe: the first record in foxes and jackals in Serbia, Vojvodina Province. Eur. J. Wildl. Res. 62, 793-796.

Liccioli, S., Catalano, S., Kutz, S. J., Lejeune, M., Verocai, G. G., Duignan, P. J. and Massolo, A. (2012): Gastrointestinal parasites of coyotes (Canis latrans) in the metropolitan area of Calgary, Alberta, Canada. Can. J. Zool. 90, 1023-1030. 
Lozanić, B. M. (1966): Contribution to the knowledge of the helminth fauna of the red fox (Vulpes vulpes L.) [in Serbian, with English abstract]. Acta Vet. Beograd 16, 301-304.

Macpherson, C. N. L. (2013): The epidemiology and public health importance of toxocariasis: A zoonosis of global importance. Int. J. Parasitol. 43, 999-1008.

Magi, M., Macchioni, F., Dell'Omodarme, M., Prati, M. C., Calderini, P., Gabrielli, S. and Cancrini, G. (2009): Endoparasites of red fox (Vulpes vulpes) in central Italy. J. Wildl. Dis. 45, 881-885.

Martinez-Carrasco, C., de Ybanez, M. R. R., Sagarminaga, J. L., Garijo, M. M., Moreno, F. A., Costa, I., Hernandez, S. and Alonso, F. D. (2007): Parasites of the red fox (Vulpes vulpes Linnaeus, 1758) in Murcia, southeast Spain. Rev. Méd. Vét. 158, 331-335.

Miterpakova, M., Hurnikova, D., Antolova, D. and Dubinsky, P. (2009): Endoparasites of red fox (Vulpes vulpes L.) in the Slovak Republic with the emphasis on zoonotic species Echinococcus multilocularis and Trichinella spp. Helminthologia 46, 73-79.

Möhl, K., Große, K., Hamedy, A., Wüste, T., Kabelitz, P. and Lücker, E. (2009): Biology of Alaria spp. and human exposition risk to Alaria mesocercariae - A review. Parasitol Res. 105, 1-15.

Otranto, D. and Deplazes, P. (2019): Zoonotic nematodes of wild carnivores. Int. J. Parasitol. Parasites Wildl. 9, 370-383.

Padgett, K. A., Nadler, S. A., Munson, L., Sacks, B. and Boyce, W. M. (2005): Systematics of Mesocestoides (Cestoda: Mesocestoididae): evaluation of molecular and morphological variation among isolates. J. Parasitol. 91, 1435-1443.

Papadopoulos, H., Himonas, C., Papazahariadou, M. and Antoniadou-Sotiriadou, K. (1997): Helminths of foxes and other wild carnivores from rural areas in Greece. J. Helminthol. 71, $227-231$.

Pavlović, I., Tambur, Z., Doder, R., Kulišić, Z. and Jakić-Dimić, D. (2008): The role of red foxes (Vulpes vulpes L.) in the epidemiology of zoonotic tapeworms of the genus Mesocestoides (Cestoda: Cyclophilidae). Veterinaria 57, 109-117.

Perić, J., Lekić, B., Reljić, V., Cirković, L. and Škiljević, D. (2017): Cutaneous Larva Migrans Report of 2 new cases locally acquired in Serbia. Serb. J. Derm. Venereol. 9, 149-153.

Rausch, R. L., Maser, C. and Hoberg, E. P. (1983): Gastrointestinal helminths of the cougar, Felis concolor L., in northeastern Oregon. J. Wildl. Dis. 19, 14-19.

Reiczigel, J., Marozzi, M., Fábián, I. and Rózsa, L. (2019): Biostatistics for parasitologists - a primer to quantitative parasitology. Trends Parasitol. 35, 277-281.

Reperant, L. A., Hegglin, D., Fischer, C., Kohler, L., Weber, J. M. and Deplazes, P. (2007): Influence of urbanization on the epidemiology of intestinal helminths of the red fox (Vulpes vulpes) in Geneva, Switzerland. Parasitol Res. 101, 605-611.

Richards, D. T., Harris, S. and Lewis, J. W. (1993): Epidemiology of Toxocara canis in red foxes (Vulpes vulpes) from urban areas in Bristol. Parasitology 107, 167-173.

Richards, D. T., Harris, S. and Lewis, J. W. (1995): Epidemiological studies on intestinal helminth parasites of rural and urban red foxes (Vulpes vulpes L.) in the United Kingdom. Vet. Parasitol. 59, 39-51.

Robinson, N. A. and Marks, C. A. (2001): Genetic structure and dispersal of red foxes (Vulpes vulpes) in urban Melbourne. Aust. J. Zool. 49, 589-601.

Romig, T. (1999): Echinococcus multilocularis in animal hosts: new data from western Europe. Helminthologia 36, 185-191.

Saeed, I., Maddox-Hyttel, C., Monrad, J. and Kapel, C. M. O. (2006): Helminths of red foxes (Vulpes vulpes L.) in Denmark. Vet. Parasitol. 139, 168-179.

Schuster, R. K., Thomas, K., Sivakumar, S. and O'Donovan, D. (2009): The parasite fauna of stray domestic cats (Felis catus) in Dubai, United Arab Emirates. Parasitol. Res. 105, 125-134.

Schweiger, A., Ammann, R. W., Candinas, D., Clavien, P. A., Eckert, J., Gottstein, B. and Tarr, P. E. (2007): Human alveolar echinococcosis after fox population increase, Switzerland. Emerg. Infect. Dis. 13, 878-882. 
Scioscia, N. P., Beldomenico, P. M. and Denegri, G. M. (2016): New host and distribution expansion for Pterygodermatites (Multipectines) affinis. Helminthologia 53, 81-86.

Seguel, M. and Gottdenker, N. (2017): The diversity and impact of hookworm infections in wildlife. Int. J. Parasitol. Parasites Wildl. 6, 177-194.

Shaw, D. J. and Dobson, A. P. (1995): Patterns of macroparasite abundance and aggregation in wildlife populations: a quantitative review. Parasitology 111, S111-S133.

Széll, Z., Tolnai, Z. and Sréter, T. (2015): Environmental determinants of the spatial distribution of Mesocestoides spp. and sensitivity of flotation method for the diagnosis of mesocestoidosis. Vet. Parasitol. 212, 427-430.

Szilágyiová, M., Laca, L., Antolová, D., Nováková, E., Rosol’anka, R., Reiterová, K. and Šimeková, K. (2015): Importance of complex diagnostic approach in differential diagnosis of alveolar echinococcosis. Helminthologia 52, 298-302.

Tasić, A., Tasić, S., Miladinović-Tasić, N., Zdravković, D. and Đorđević, J. (2007): Prevalence of Dirofilaria repens - cause of zoonosis in dogs. Acta Facultatis Medicae Naissensis 24, 72-75.

Tomović, M., Skiljevic, D., Zivanovic, D., Tanasilovic, S., Vesic, S. and Dakovic, Z. (2008): Two cases of probable endogenous extensive cutaneous larva migrans in Serbia. Acta Dermatovenerol. Alp. Pannonica Adriat. 17, 37-40.

Vergles-Rataj, A., Posedi, J., Zele, D. and Vengušt, G. (2013): Intestinal parasites of the red fox (Vulpes vulpes) in Slovenia. Acta Vet. Hung. 61, 454-462.

Vervaeke, M., Dorny, P., De Bruyn, L., Vercammen, F., Jordaens, K., Berge, K. and Vhagen, R. (2005): A survey of intestinal helminths of red foxes (Vulpes vulpes) in northern Belgium. Acta Parasitol. 50, 221-227.

Vervaeke, M., Van den Berge, K., Vercammen, F., Geerts, S., Brandt, J., Dorny, P. and Verhagen, R. (2003): Echinococcus multilocularis (Cestoda, Taeniidae) in red foxes (Vulpes vulpes) in northern Belgium. Vet. Parasitol. 115, 257-263.

Walton, Z., Samelius, G., Odden, M. and Willebrand, T. (2018): Long-distance dispersal in red foxes Vulpes vulpes revealed by GPS tracking. Eur. J. Wildl. Res. 64, 64.

Ziadinov, I., Deplazes, A., Mathis, A., Mutunova, B., Abdykerimov, K., Nurgaziev, R. and Torgerson, P. R. (2010): Frequency distribution of Echinococcus multilocularis and other helminths of foxes in Kyrgyzstan. Vet. Parasitol. 71, 286-292. 